\title{
IMPLEMENTATION OF TEXT TRANSFORMATION IN PHYSICS EDUCATION TO REDUCE STUDENTS' MISCONCEPTION
}

\author{
Soeharto ${ }^{1)}$ \\ ${ }^{2)}$ STKIP Singkawang, Jl. STKIP Kelurahan Naram, Singkawang, Indonesia \\ E-mail: soehartofisika@gmail.com
}

\begin{abstract}
This research aimed to know the effect of text transformation in educational physics especially Impuls and momentum to reduce students' misconception. This study was held at state senior high school (SMAN) 2 in Pontianak, West Borneo. The instrument in this study has made with diagnostic test using certainly of responden index method. The research design in this study using one group pretest-posttest design. Population in this research is all students of science major in state senior high school 2 in Pontianak. This study have found that implementation of text transformation giving effect significantly to reduce students' misconception according Wilcoxon test $(Z=-3,418, p=$ 0.01). However, this research is not finding corelation which is significantly between skill to make a note using text transformation and reduction of students' misconception $\left(\tau_{a}=0.119, \mathrm{p}=0.490\right)$. The value of effect size in this research is 1.65 .
\end{abstract}

Keywords: misconception, implementation, text transformation

\section{INTRODUCTION}

Over the past 25 years the construct of situasion awarness debates concept, isunderstandings, and misconceptions aside, where does the operational community stand with respect to the construct of situasion awarness [1]. Physicists might have done the most to study their students' misconceptions and then acted on their findings. They utilize "concept inventories" to assess students' conceptual understanding. That is, rather than asking students to perform calculations, students are asked questions that probe their conceptual framework. Distractors in these assessments are common student misconceptions that have been discovered through careful research [2]

Concepts can be considered as ideas, objects or events that help us understand the world around us [3]. Misconceptions, on the other hand can be described as ideas that provide an incorrect understanding of such ideas, objects or events that are constructed based on a person's experience Martin (2002) [4] including such things as preconceived notions, nonscientific beliefs, naïve theories, mixed conceptions or conceptual misunderstandings [5].

Distinguishing between different qualities of conceptual understanding and between phenomenonbased and modelbased conceptualizations as well as considering processes of concept formation offers insights into students' misconceptions. Some misconceptions occur as a result of students repeated experiences with phenomena of their everyday world [6].

Piaget suggests that children search for meaning as they interact with the world around them [3] and use such experiences to test and modify existing schemas. There are many possible sources for the development of misconceptions. First, not all experiences lead to correct conclusions or result in students seeing all possible outcomes. Second,when parents or other family members are confronted with questions from their children, rather that admitting to not knowing the answer, it is common for them to give an incorrect one.Another research from Philips Sadler (2013) found that misconception which students gain are related with teacher knowledge which is analogy in Figure 1.

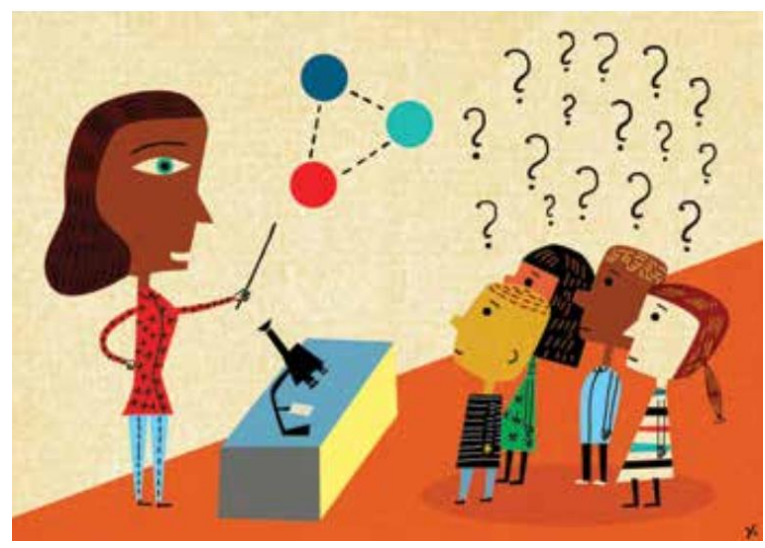

Fig 1. analogy picture about relation students and teacher misconception [7].

Misconceptions themselves can be related to such things as misunderstanding factual information or being given conflicting information from credible sources such as 
parents and teachers. The big issues are that once a misconception has been formed, it is extremely difficult to change and that possessing misconceptions can have serious impacts on learning [8].

The misconception is a lot happening in the field of physics. Wandersee, Mintzes and Novak [9] states that occur misconceptions in all areas of physics. Among these 700 studies on misconceptions in physics, there are 300 misconceptions about mechanics; 159 on electricity; 70 about the heat, optics, and material properties; 35 about earth and space; as well as 10 study of modern physics. Mechanics, ranks first, most students who have misconceptions, because the mechanics become the main starting materials and in high school, so the field was widely studied. Research Ayse Gul and Musta Sabri (2008) [10] found many students had misconceptions about momentum, approximately $63.3 \%$ of students experiencing misconceptions about the impulse and momentum. Findings were similar occurs also among high school students of State in Pontianak. In addition, the average value of the midterm physics academic year 2012/2013 in the class XI SMAN 2 Pontianak just 53.56. Many students who have misconceptions of physics concepts. Therefore, there needs remediation activities that help students overcome these misconceptions. Master class XI SMAN 2 Pontianak stated that he not understand what is meant remediation. This statement, strengthen remediation activities undertaken in the research. Text Transformation Shaped Note: TS Text transformation aided Hypermedia software for the first time introduced by Ted Nelson. [11]. Text tranformation has been widely used in research in the field of education. Text transformation in physical education have been developed by Victor Lopes (2010) [12]. Text transformation is currently included in the curriculum developed by the National Center on acessing the General Curriculum (NCAC) in America. However, the text transformation has not been studied in Indonesia. Text transformation is an activity to alter or modify the text from its original form to forms other grain [13]. Briefly implementation of software-aided transformation hypermedia text is presented in Figure 2.

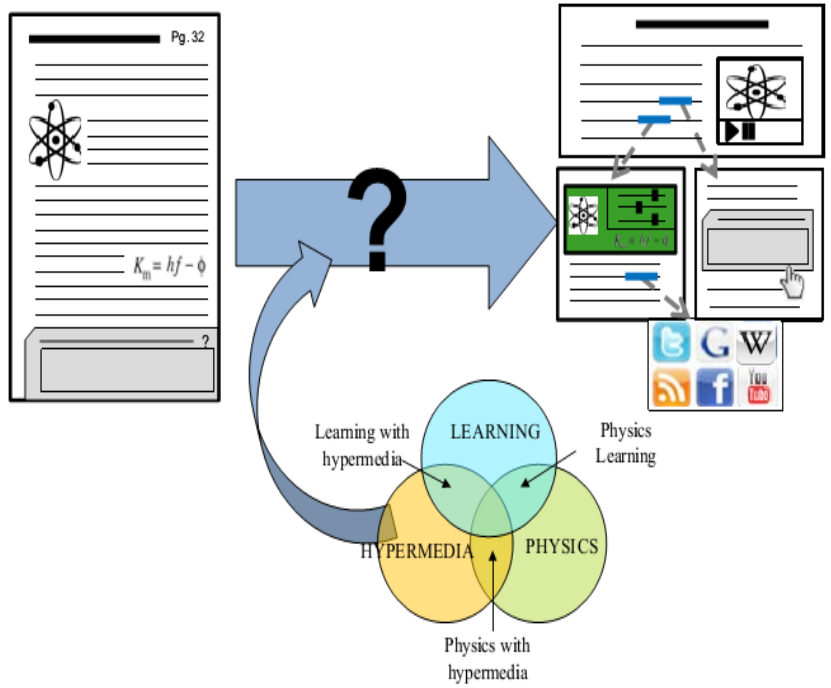

Fig 2. Text Transformation using hypermedia software (Lopes, 2011: 3)

However, the text transformation aided Hypermedia software is difficult to do in a research study because Hypermedia software must be connected to the Internet and is a paid software. This study used the Text transformation shaped note: TS.

Note: TS is short for "Note: Write and Compose". Note: TS-record consists of writing and preparation of records. Writing-record is a record of what was presented in the textbook. Preparation of-record is written about thoughts, impressions, feelings, reactions or questions students when studying a textbook. Note: TS including engineering recorded a high level that can help students improve memory [14].

Text transformation shaped note: TS can help students construct their own knowledge because during studying textbook, students write their responses. Mark Reardon [14] has been using the technique note: TS in training SuperCamp. Shape note: TS created by Mark Reardon presented in Figure 3 


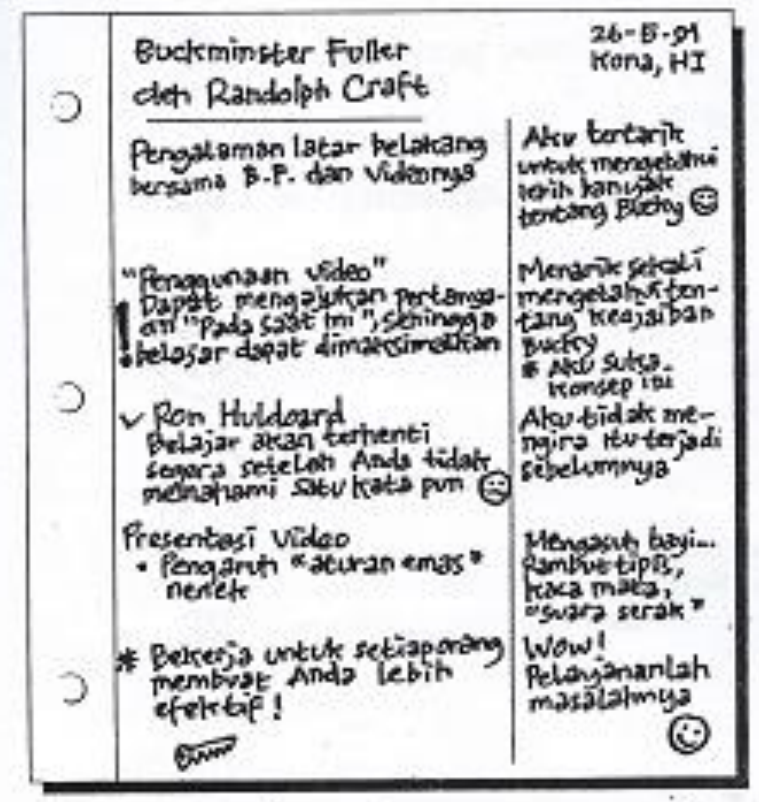

Fig 3. Form of Note: TS Made by Mark Reardon [14]

Text transformation shaped note: TS in this research, mentrastranformasikan textbook high school physics class XI, entitled "Physics for Senior High School 1st Semester Grade XI". This book is a bilingual version of the package authored by Marten Kanginan. Text transformation shaped note: TS is expected to improve learning outcomes, especially in the matter of impulse and momentum. The intended learning outcomes in this study is the result of the initial test (pre-test) and final test (post-test). The difference of the results of the initial test (pre-test) and final test (posttest) will illustrate changes in the number of misconceptions. Briefly application of text transformation shaped note: TS presented in Figure 4

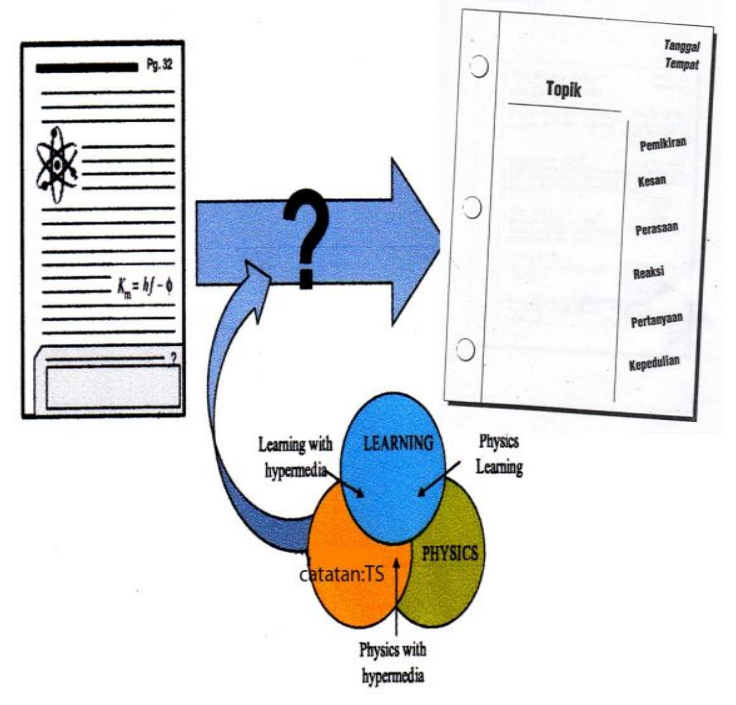

Fig 4. Text Transformation shaped Note:TS

This research in the form of remediation using 'text transformation' shaped Note: TS geared to help students overcome misconceptions about the impulse and momentum. Text transformation is an activity to alter or modify the text from its original form to a form more grain [13]. In a study conducted, the text in the textbook converted into a note: TS. Note: TS is short for "Note: Write and Compose". Note: TS-record consists of writing and preparation of records. Writing-record is a record of what was presented in the textbook. Preparation of records means that writing about thoughts, impressions, feelings, reactions or questions students when studying textbook [14]. It is expected to make a note: TS, students can construct their own knowledge.

Text transformation shaped note: TS in this research, mentrastranformasikan textbook high school physics class XI, entitled "Physics for Senior High School 1st Semester Grade XI". This book is a bilingual version of the package authored by Marten Kanginan. Text transformation shaped note: TS is expected to reduce the number of misconceptions in students especially the material impulse and momentum.

Issues that will be answered this study is whether to use a text transformation remediation shaped note: TS effect on decreasing the number of misconceptions students, especially in the matter of impulse and momentum. Moreover, given the text transformation that followed did make a note: TS is a skill it is also questionable how much the relationship between the magnitude of the decline of these skills with student misconceptions.

\section{METHOD}

This is experimental research. This research is made using review some journal, article some literatures and analyzing data of students' misconception in physics especially in impuls and momentums. Form of the research in the form of pre-experimental design with the design of one group pretest-posttest design is presented in TABLE 1.

TABLE 1: One Group Pretest-Postest Design

\begin{tabular}{ccc}
\hline Pre-test & Treatment & Post-test \\
\hline $\mathrm{O}_{1}$ & $\mathrm{X}$ & $\mathrm{O}_{2}$ \\
\hline
\end{tabular}

Students (102) at SMAN 2 Pontianak who has followed the subjects of physics at the material impulse and momentum in grade XI of the school year 2012/2013 target. By way of intact group have all students of class XI IPA3 as a sample. However, only 25 students who follow all the action. Therefore the data from these were analyzed. Misconceptions about the students dug with 27 multiple choice diagnostic tests. The validity of pre-test was 4.07 and the post-test was 4.10 on a scale of $1-5$, while the level of reliability of each are 0.584 and 0.564 . 


\section{RESULT AND DISCUSSION}

Result

Normality test (Kolmogorov-Smirnov) showed that the number of misconceptions from every students pre-test results are not normally distributed $(p=0.711, \alpha=0.05)$. Therefore, data analysis using nonparametric statistical tests (Wilcoxon and Kendall rank correlation $\left(\tau_{-} a\right)$ ). Wilcoxon and Kendall rank correlation ( $\tau_{-}$a) selected for the data in the form of scores are ranked, both variables are ordinal scale (large-small sequential) [16].

Wilcoxon analysis showed that there was a significant effect of this remediation activities, the decrease in the number of misconceptions from every student $(Z=-3.418, p$ $=0.01)$ in. calculation of the effect size of 1.65 to find the price barometer effect size John Hattie (2009). It was concluded that the effect of remediation is high.

Kendall rank correlation analysis $(\tau$ a $)$, TABLE 2 showed no significant correlation between accuracy in making note: TS and changes the number of student misconceptions $(\tau=$ $0.119, \mathrm{p}=0.490)$.

TABLE 2 Result of analysis Kendall's tau

\begin{tabular}{lllll}
\hline & & & $\begin{array}{l}\text { Change } \\
\text { Number of } \\
\text { Misconception }\end{array}$ & note:TS \\
\hline $\begin{array}{l}\text { Kendall's } \\
\text { tau_ } \alpha\end{array}$ & $\begin{array}{l}\text { Change } \\
\text { Number of } \\
\text { Misconception }\end{array}$ & $\begin{array}{l}\text { Correlation } \\
\text { Coefficient }\end{array}$ & 1.000 & .119 \\
\cline { 3 - 5 } & $\begin{array}{l}\text { Sig. (2- } \\
\text { tailed) }\end{array}$ &. & .490 \\
\cline { 3 - 5 } & $\mathrm{N}$ & 25 & 25 \\
\hline
\end{tabular}

\section{Discussion}

This research found the effect of remediation using text transformation shaped note: TS against reduction in the number of misconceptions persiswa $(Z=-3.418, p=0.01)$ in the effect size $(E S=1.65)$. This finding is consistent with other research, Ayse Gul and Musta Sabri (2008), Rio Rikardo (2008), and Emi Sulistri (2010) [10], [17], [18]. This finding is also consistent with research conducted by Victor Lopes (2011) [12], although there are differences of this type of research used and modified treatment. Victor Lopes research shaped experimental research and treatmentnya transform text in the textbook with hypermedia software. Text transformation is done with the help of hypermedia software converted into three forms of hypertext, interactive applications and multimedia files.

This study found no significant correlation $\left(\tau_{-} \mathrm{a}=0.119, \mathrm{p}\right.$ $=0.490$ ) between the ability to make notes: TS and changes in the number of students misconceptions. This fact, probably caused by students who first received training make a note: TS. Students are used to record the teacher's explanations on the board, so that students' difficulties when instructed to make a note: TS their own and write the responses. Another drawback may be caused by the availability of data, which are not restricted only guess that does not represent the actual occurrence of the complete course there is also a weakness caused by design choice.

\section{CONCLUSIONS}

This research found the effect of remediation using text transformation shaped note: TS significant change in the number of students' misconceptions $(\mathrm{Z}=-3.418, \mathrm{p}=0.01)$ in the ES 1.65. The average percentage decrease in the amount of $50.53 \%$ each student misunderstanding. The correlation between the ability to make notes: TS and changes in the number of students is not significant misunderstanding ( $\tau_{-}$a $=0.119, \mathrm{p}=0.490$ ).

Based on the research conducted, put forward some suggestions as follows: (1) is recommended before remediation using text transformation shaped note: TS in learning activities, students are given special training in making note: TS, (2) for further research, it is recommended to be taken on development of text transformation, such as to text transformation of textbooks, apart form the record: TS, (3) should be used in the form of better research for instance true experiment, with the draft "pretest-posttest control group design", so as to minimize the factors that influence internal validity, (4) preferably after the data are grouped using CRI modified method, conducted interviews outside the remediation activities to students who belong to guess in order to represent a complete data.

\section{ACKNOWLEDGMENT}

We would like to thank ADRI which provides template to help all participants writes a journal easily and conducts this international seminar. We would like to thank to STKIP Singkawang which fund all of cost to present this research and some lecturers who give advices to make better idea in this research. Without all of people who support this research, we cannot write this research well and properly.

\section{REFERENCES}

[1] Byrne. E. (2015). Commentary on Endsley's "Situation Awareness Misconceptions and Misunderstandings". Journal of Cognitive Engineering and Decision Making. (1),pp 84-86.

[2] Goffe, William L. (2013), "Initial Misconceptions in Macro Principles Classes", mimeo, accessed in September 2016 from http://cook.rfe.org/

[3] Eggen, P. and Kauchak, D. (2004) Educational Psychology: Windows, Classrooms. Upper Saddle River: Pearson Prentice Hall

[4] Martin, R., Sexton, C. and Gerlovich, J. (2002) Teaching Science for all Children: Methods for Constructing Understanding. Boston: Allyn and Bacon

[5] Hanuscin, D. (n.d.) Misconceptions in Science E328: Elementary Methods.[Online]http://www.indiana.edu/ w505a/studwork/deborah/. [20/11/2016]

[6] Aufschnaiter, V. C. And Rogge, C.(2010).Misconceptions or Missing Conceptions?. Eurasia Journal of Mathematics, Science \& Technology Education, 2010, 6(1), 3-18.

[7] Sadle, M. P. rand Sonnert, G. (2016). Understanding Misconception. American Educator. Spring 2016

[8] Thomson, F. And Logue, S. (2006). An exploration of common student misconceptions in science. International Education Journal, 2006, 7(4), 553-559.

[9] Suparno, Paul. (2005). Miskonsepsi dan perubahan Konsep dalam Pendidikan Fisika. Jakarta: Grasindo.

[10] Gul, Ayse dan Mustafa Sabri. (2008). Grade 10 Student' Misconception about Impulse and Momentum. Journal of Turkish Science Education. 5(1) 44-48.

[11] Wang, Hong. (2003). "Hypemedia: A Brief Literature Review", Journal of Education Computing, Design \& Online Learning. 
(Online).(http://coeksu.edu/jecdol/Vol_4/Articles/pdfs/Hong\%20_Hy permedia_.pdf, 2 Desember 2012)

[12] Lopes, Victor. (2012). "From Linier Text to Hypermedia in Physics Educational Documents". Research Center for Science and Mathematics Education. (Online). (http://www.univreims.fr/site/evenement/girep-icpe-mptl-2010-eims-internationalconference/gallery files/site/1/90/4401/22908/29321/29677.pdf, Desember 2012).

[13] Strangman, Nicole dan Tracey Hall. (2012). "Text Transformation". National Center on Accesing the General Curriculum (NCAC). http://aim.cast.org/learn/historyarchive/backgroundpapers/text transf ormations, Desember 2015).

[14] DePorter, Bobbi dan Mike Hernanchi. (2000). Qantum Learning. (Translator: Alwiyah Abdurrahman). Bandung: Kaifa.

[15] Sugiyono. (2011). Metode Penelitian Pendidikan. Bandung: Alfabeta.

[16] Sutrisno, L. (2013, 7 april,:2). Memilih Analisis Statistika Bivariate. Pontianak Post.

[17] Rikardo, Rio. (2008). Miskonsepsi Siswa Kelas XI SMA Negeri 1 Teluk Keramat Tentang Hukum Kekeklan Momentum. Skripsi. Pontianank: FKIP UNTAN (thesis).

[18] Sulistri, Emi. (2010). Efektivitas Kegiatan Remediasi untuk Mengatasi Miskonsepsi Siswa: Sebuah Rangkuman Meta-analisis Skripsi Mahasiswa Program Studi Pendidikan Fisika FKIP UNTAN 2009. Pontianak: FKIP UNTAN (thesis). 